\title{
Influence of increasing doses of intestinal digestible methionine (MetDI) on the performance of dairy cows in mid and late lactation
}

\author{
JC Robert, BK Sloan, F Lahaye
}

\section{Rhône Poulenc Animal Nutrition, 03600 Commentry, France}

Two trials were performed : the first with 10 primiparous and 10 multiparous dairy cows from the 17th to 26 th weeks of lactation and the second with 5 primiparous and 5 multiparous dairy cows from the 28th to the 37 th weeks of lactation. Both trials were conducted according to a Latin square design $(5 \times 5)$; periods of two week duration. Five supplementary doses of MetDI were tested : 0 (T1), 2.7 (T2), 5.5 (T3), 8.3 (T4), and $11.5 \mathrm{~g}$ (T5), using the SmartamineTM technology of Rhône Poulenc Animal nutrition. Maize silage was offered ad libitum, plus soyabean meal and a concentrate containing ( $\%$ ) : beet pulp 30 , barley 20 , formaldehyde treated soyabean meal 16 , wheat bran 10 , forage peas 10 , beet molasses 8 , tallow 4 , and urea 0.17 . In both trials the soyabean meal and the concentrate were fed according to predicted milk yield. On average the former accounted for $15 \%$ of the total ration in both trials, the latter accounting for $15 \%$ in trial 1 and $5 \%$ in trial 2 . The rations covered respectively 106 and $115 \%$ of net energy and 122 and $125 \%$ of PDI requirements. The calculated level of digestible lysine (lysDI) as a \% of PDIE (H Rulquin, et al,
Journées CAAA-AFTAA, le Mans 22-23 Juin 1993) was 7 and MetDI (\% PDIE) was 1.76 , $1.91,2.06,2.21$, and $2.36 \%$ for the 5 rations tested.

Milk production and intakes were individually controlled every day. Milk composition (fat, protein and lactose) was determined individually at six consecutive milkings and casein and urea concentrations at one milking per week.

In trial 1 , milk protein and milk casein content were significantly improved $(P<0.05)$ by increasing level of MetDI in the ration, the maximum response corresponded to the ration MetDI level of $2.2 \%$ PDIE. Equally milk protein content was improved in trial 2 the maximum response corresponded to the ration MetDI level of $2.1 \%$ PDIE. These results confirm that increasing the MetDI level in rations well covered in lysDI can improve the milk protein content of cows in mid and late lactation similarly to the observations made in early lactation dairy cows (Rulquin and Delaby, 1994, J Dairy Sci, Vol 77, Supp 1, 91).

\begin{tabular}{|c|c|c|c|c|c|c|c|c|c|c|c|c|}
\hline \multirow[b]{2}{*}{ Treatment } & \multirow[b]{2}{*}{ T1 } & \multicolumn{5}{|c|}{ Trial 1} & \multicolumn{6}{|c|}{ Trial 2} \\
\hline & & T2 & T3 & $\mathrm{T} 4$ & T5 & SED & T1 & T2 & T3 & T4 & T5 & SED \\
\hline$(\mathrm{kg} / \mathrm{d})$ & 19.7 & 19.5 & 19.8 & 19.8 & 19.6 & 0.25 & 18.2 & 17.8 & 18.0 & 18.1 & 17.9 & 0.47 \\
\hline Milk Yield $(\mathrm{kg} / \mathrm{d})$ & 25.5 & 25.4 & 25.5 & 25.2 & 25.1 & 0.22 & 19.5 & 19.5 & 19.3 & 19.8 & 19.2 & 0.36 \\
\hline ant & $31.7^{a}$ & $32.1^{\mathrm{ab}}$ & $32.3^{b}$ & $32.6 \mathrm{~b}$ & $32.5^{b}$ & 0.17 & $34.0^{\mathrm{a}}$ & $34.3 \mathrm{ab}$ & $35.0^{\mathrm{b}}$ & $34.4 \mathrm{ab}$ & $34.5 \mathrm{ab}$ & 0.32 \\
\hline rote & 805 & 809 & 820 & 816 & 808 & 8.9 & 658 & 662 & 676 & 679 & 660 & 11.5 \\
\hline Casein Content ( $\mathrm{g} / \mathrm{k}$ & 26.0 & 26.4ab & $26.7 \mathrm{bc}$ & $c 26.8 \mathrm{c}$ & $26.7 \mathrm{bc}$ & 0.15 & 28.0 & 27.9 & 28.6 & 28.0 & 28.3 & 0.3 \\
\hline
\end{tabular}

Means with different superscripts indicate a significant difference $(P<0.05)$ 